\title{
Incidence of Sternalis Muscle in the Caldas Population (Colombia): Anatomical Variations
}

\author{
Incidencia del Músculo Esternal en la Población de Caldas (Colombia): Variaciones Anatómicas
}

Jorge Eduardo Duque-Parra ${ }^{1,2}$; John Barco-Ríos ${ }^{1}$ \& Juan Fernando Vélez-García ${ }^{3}$

DUQUE-PARRA, J. E.; BARCO-RÍOS, J. \& VÉLEZ-GARCÍA, J. F. incidence of sternalis muscle in the Caldas population (Colombia): Anatomical variations. Int. J. Morphol., 37(4):1342-1346, 2019.

SUMMARY: The musculus sternalis is an anatomical variant that occurs in 3-8 \% of the world population and its incidence is higher in women. It can be found unilaterally or bilaterally and is located in the anterior wall of the thorax, where its fibers run parallel to the sternum and superficial to the medial part of the pectoralis major muscle. The main objective of this study was to quantify the incidence of musculus sternalis in the population of Caldas (Colombia) and, therefore, 68 cadavers of adult individuals were used during a period of twenty years to determine the incidence of this muscle and describe its anatomical characteristics. Two cadavers had this muscle, which was equivalent to $2.94 \%$ of the sample, where one was located unilaterally and in other bilaterally. In the case of unilateral presence, the muscle presented an oblique direction thatdoes not coincide with any subtype of the classification given for these muscles. In bilateral presentation, both muscles were continuous at their upper ends with the respective sternocleidomastoid muscle. In addition, the right musculus sternalis had a digastric shape, which also does not coincide with any subtype of the classification.

KEY WORDS. Miology; Musculus esternalis; Pectoralis major muscle; Anatomical variation.

\section{INTRODUCTION}

The musculus sternalis is an inconsistent and very uncommon structure of the muscles of the anterior thoracic wall (Poveda et al., 2013), with a frequency of presentation that varies among different ethnic groups, being higher in the Chinese population at $23.5 \%$ and the lowest in the Taiwanese population at $1 \%$ (Raikos et al., 2011; Vishal et al., 2013), while in the European population its incidence is $4.4 \%$ and in the African population $8.4 \%$ (Loukas et al., 2004). Due to its low presentation, the sternal muscle is considered an anatomical variant, and it is referenced in the Terminologia Anatomica with the alphanumeric code A04.4.01.001 (Federative International Committee on Anatomical Terminologies, 1998). It can be partially or completely absent (Standring, 2016), and additionally it can have a unilateral or bilateral presentation (Young Lee et al., 2006), where the first is more frequent (Mehta et al., 2010); furthermore, its prevalence is higher in women than in men. (Aguado-Henche et al., 2018).

The musculus esternalis has a subcutaneous location in the thoracic wall (Marques et al., 2009), adjacent to the lateral margin of the sternum and superficial to the medial part of the pectoralis major muscle. Its fibers extend between the upper part of the sternum or infraclavicular area until the sheath of the rectus abdominis muscle, costal cartilage or aponeurosis of the external oblique abdominal muscle (Jelev et al., 2001). Other authors describe that its fibers originate in the fascia of the rectus abdominis muscle and insert onto the pectoralis fascia, the upper part of the sternum or the heads of the sternocleidomastoid muscle (Poveda et $a l$.; Standring). In another finding, it was described as originating in the sternal manubrium through a flattened tendon and inserting onto the pectoral fascia at the level of the 4 and 5 or 5 and 6 costal cartilages (Hung et al., 2012). Due to these different presentations, the muscle has been known by other names, such as epiesternal, parasternal, presternal, sternal rectus, and rectus thoracis (Jelev et al.); however, the latter name (rectus thoracis muscle) corresponds to another constant muscle that is found in domestic mammals, which originates in the first rib and inserts in the ventral end of the ribs 2 to 4 (Hermanson, 2013). Additionally, it is deep to the pectoral muscles (Hermanson),

\footnotetext{
${ }^{1}$ Departamento de Ciencias Básicas, Facultad de Ciencias para la Salud, Universidad de Caldas, Manizales, Colombia.

${ }^{2}$ Departamento de Ciencias Básicas, Facultad de Ciencias para la Salud, Universidad de Manizales, Manizales, Colombia.

${ }^{3}$ Departamento de Sanidad Animal, Facultad de Medicina Veterinaria y Zootecnia, Universidad del Tolima, Ibagué, Colombia.
} 
therefore, this is not homologous to the musculus esternalis. Furthermore, it should not be confused with the sternocostal or supracostal muscles (Diogo \& Abdala, 2010; Diogo \& Wood, 2012).

The innervation of the musculus esternalis is also variable, since in $43 \%$ of the cases it is by the anterior cutaneous branches of the intercostal nerves (O'Neill \& Folan-Curran, 1998; Jelev et al.; Motabagani et al., 2004), whereas in $55 \%$ it is by the pectoral nerve (O'Neill \& FolanCurran; Kida et al., 2000; Kumar et al., 2003; Hung et al.), and in $2 \%$ it is by a combination of both nerves ( $\mathrm{O}^{\prime} \mathrm{Neill} \&$ Folan-Curran). The motor function of the musculus esternalis is still unknown (Jelev et al.; Poveda et al.; Hung et al.); however, based on its origins and insertions, it has been proposed as a muscle that could contribute to the elevation of the lower thoracic cage according to planar vector mechanics, thus, it could participate minimally as an accessory muscle to inhalation. This is as it is associated functionally with the costochondral joints, which are directed toward to sternocostal joints, thus allowing movements of costal elevation (Hung et al.). Regarding this muscle, other authors have also suggested that it could have a proprioceptive function in order to detect the movements of the anterior thoracic wall (Zaher et al., 2009). However this proposition, leads us to more questions than answers because currently, the presence of muscular spindles has not been reported, and the other hand, this does not explain why its unilateral presence is greater than bilateral. Additionally, other authors consider it useful in reconstructive surgeries in the head and neck (Katara et al., 2013; Vishal et al.; Harish \& Gopinath, 2003).

\section{MATERIAL AND METHOD}

For this investigation, 68 cadavers of adult individuals (65 males and 3 females) present in the anatomy laboratory of the University of Caldas between 1998 and 2018 were used. All the principles of the declaration of Helsinki for medical research were followed, respecting the anatomical parts obtained for this study. The confidentiality of the personal information of the cadaver was respected, safeguarding their dignity and integrity. The requirements established in Resolution 8430 of the Ministerio de Salud were respected also (Ministerio de Salud, 1993) (this entity governs the biomedical research in Colombia). This study also was approved by the Bioethics Committee of the Universidad de Caldas. The cadavers were previously fixed with $10 \%$ formalin. Gross dissections were performed, where the skin of the anterior thoracic wall was removed to check for the presence of the musculus esternalis. A detailed anatomical description was given for each finding, characterizing its shape, location, direction, origin, insertion and measurements. Photographic records were taken during the process. The measurements were made with a digital caliper.

\section{RESULTS}

On the 68 bodies reviewed, the musculus sternalis was found in two males, which corresponds to $2.94 \%$ of the total of sample. In one cadaver, this muscle was present unilaterally $(1.47 \%)$ and in the other cadaver was bilaterally $(1.47 \%)$.

Case 1: Unilateral presence of musculus esternalis with thoracothoracic location. The muscle was located in the left hemithorax, with a triangular shape and projected obliquely from medial to lateral. Its origin was from the sternal manubrium by a slightly arched tendon $4.7 \mathrm{~cm}$ long and 0.7 $\mathrm{cm}$ wide; while its insertion was onto the fifth costal cartilage through three bundles of connective tissue, which was on average $2.2 \mathrm{~cm}$ long and $3.1 \mathrm{~cm}$ wide. The flesh belly ran superficially in the medial part of the pectoralis major muscle being $8.3 \mathrm{~cm}$ long and $5 \mathrm{~cm}$ wide. Finally, the total length of this muscle was $15.2 \mathrm{~cm}$ (Fig. 1).

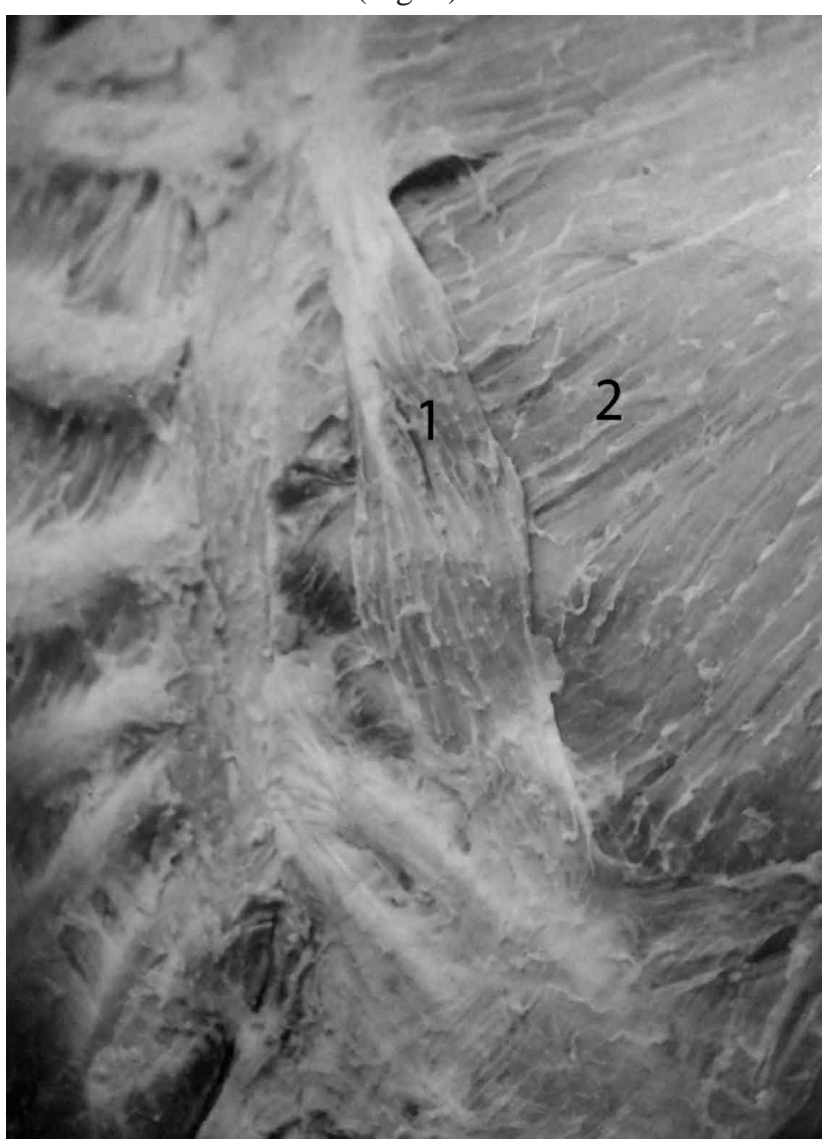

Fig. 1. Unilateral presence of musculus esternalis with thoracothoracic location. 1) Musculus esternalis, 2) Pectoralis major muscle. 
Case 2: Bilateral presence of the musculus esternalis with cervicothoracic location. In these muscles the upper ends continue with their respective sternocleidomastoid muscle, and in their lower ends continue with the fascia of the seventh intercostal muscles. Both muscles were fusiform and project longitudinally parallel to the sternum, located superficially in the medial part of the pectoralis major muscle. The musculus sternalis of the right side had an unusual shape, the presence of two fleshy bellies, its origin was on the lateral edge of the sternal manubrium through a fleshy portion $1.1 \mathrm{~cm}$ wide and $2.8 \mathrm{~cm}$ long, and at the level of the third costal cartilage was continued with a flattened tendon $0.6 \mathrm{~cm}$ wide and $3.3 \mathrm{~cm}$ long. The other muscular belly was $1.2 \mathrm{~cm}$ wide and $4.8 \mathrm{~cm}$ long. Its insertion was through of a tendon $6.5 \mathrm{~cm}$ long that forms an arch towards lateral to end in the seventh costal cartilage, with a width of $0.3 \mathrm{~cm}$ at its attachment point. The total length of the right sternal muscle was $17.4 \mathrm{~cm}$. The muscle on the left side was originated on the lateral edge of the sternal manubrium through a flattened tendon $0.5 \mathrm{~cm}$ wide and $3.6 \mathrm{~cm}$ long, continuing with a fleshy belly $1.2 \mathrm{~cm}$ wide and $6.9 \mathrm{~cm}$ long. Its insertion was onto the seventh costal cartilage through two tendinous bands, which were arched and flattened from medial towards lateral being $0.3 \mathrm{~cm}$ wide and $3.3 \mathrm{~cm}$ long. The total length of the left sternal muscle was $13.8 \mathrm{~cm}$ (Fig. 2).

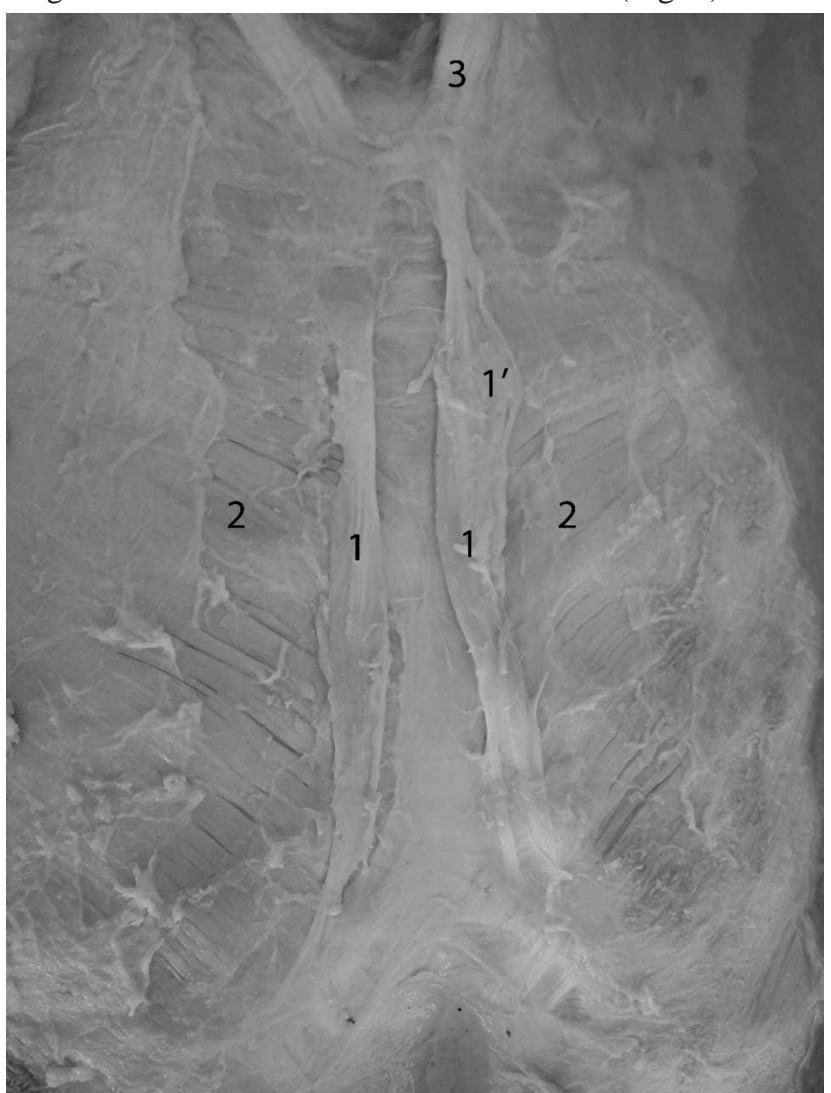

Fig. 2. Bilateral presence of the musculus esternalis with cervicothoracic location. 1) Musculus estaernalis, 1') Accessory belly, 2) Pectoral major muscle.

\section{DISCUSSION}

According to different studies, the musculus esternalis is a normal anatomical variant that can be found unilaterally or bilaterally between $3 \%$ and $8 \%$ of the world's population (Pérez et al., 2008), but other studies show other percentages according to different ethnic groups, being as high as $23.5 \%$ for Northern China and as low as $1 \%$ for Taiwan (Jelev et al.). Our study reveals that according to the sample analyzed, the incidence of the musculus esternalis in the population of Caldas (Colombia) was of $2.94 \%$, which is a value that is within the range reported for other population groups.

In non-human primates this muscle is usually absent (Diogo \& Wood), it has not even been named among the variants of the pectoral muscles in Chimpanzees and Bonobos (Potau et al., 2018), however it has been found variably in Hylobates syndactylus (Van der Broek, 1909). Thus, there must be a phylogenetic factor that makes it also appear in the human, and although Lander (1918) describes its homologous presence in Cebus capucinus, this is not the musculus esternalis, since he finds it into deep to the pectoralis minor muscle and according to his description, it corresponds to the thoracic rectus muscle.

None of the anatomical characteristics of the musculus esternalis found in this study coincide with the categories proposed by Jelev et al. In case 1, where the presentation is unilateral, the muscle runs clearly obliquely, from the sternal manubrium to the fifth costal cartilage in the left hemithorax, superficially crossing the pectoralis major muscle through its medial region, which is a characteristic that does not coincide with any of the subtypes proposed by Jelev et al. Case 2, where the presentation is bilateral, also corresponds to a very rare finding (Preeti et al., 2012; Cherian \& Gandhalam, 2014). Both muscles are parasternal and their fibers run parallel to the lateral edges of the sternum and medial to the pectoralis major muscles. In addition, the right sternal muscle is digastric, which is a variation reported as quite unusual in the literature (Guru et al., 2013) and which does not appear in the classification given by Jelev et al., even as it continues at its upper end with the sternocleidomastoid muscle, coinciding with reports by other authors (Poveda et al.; Standring). The left sternal muscle shows a single belly, which coincides with the subtype I1 of the Jelev et al. classification; however, it continues ipsilaterally at its upper end with the sternocleidomastoid muscle, similar to the right esternalis muscle, which corresponds to another variant reported by Mehta et al. 
Although the incidence of the musculus esternalis in the world population is low, clinicians must take into account the possibility of visualizing this muscle through mammography, magnetic resonance or axial computed tomography of the chest (Marques et al.; Rahman et al., 2009) since it could simulate a neoplasia (Young Lee et al.; Aguado-Henche et al.). As such, its recognition could avoid the unnecessary performance of additional imaging studies, biopsies and exploratory surgeries (Kumar et al.; Aguado-Henche et al.,) that generate medical costs to the health system, in addition to stress and unjustified anxiety caused to the patients (Poveda et al.).

\section{CONCLUSION}

The musculus esternalis has an incidence of 2.94 $\%$ in the population of the Department of Caldas (Colombia), which corresponds to a value a little below the range of presentation for the world population that is between 3 $\%$ and $8 \%$. The muscles found in our study have unusual anatomical characteristics and do not coincide with any of the subtypes of the classification made by Jelev et al.

DUQUE-PARRA, J. E.; BARCO-RÍOS, J. \& VÉLEZGARCÍA, J. F. Incidencia del músculo esternal en la población de Caldas (Colombia): Variaciones anatómicas. Int. J. Morphol., 37(4):1342-1346, 2019,

RESUMEN: El músculo esternal es una variante anatómica que se presenta entre el $3 \%$ y $8 \%$ de la población mundial y su incidencia es mayor en mujeres. Puede hallarse de manera unilateral o bilateral y se localiza en la pared anterior del tórax, donde sus fibras corren paralelas al esternón y superficial a la región medial del músculo pectoral mayor. El objetivo del presente estudio fue cuantificar la incidencia del músculo esternal en la población de Caldas (Colombia). Fueron revisados 68 cadáveres de individuos adultos durante un lapso de doce años, con el fin de determinar el grado de presencialidad del músculo y sus características anatómicas. Dos cadáveres, que equivale al 2,94 $\%$ de la muestra, presentaron el músculo esternal, uno de manera unilateral y el otro bilateral, a los cuales se les hizo una descripción anatómica detallada. En la presentación unilateral, el músculo presentó una dirección oblicua que no coincide con ningún subtipo de la clasificación dada para estos músculos. En la presentación bilateral, ambos músculos se continúan por su extremo superior con el respectivo músculo esternocleidomastoideo. Además, el músculo esternal derecho tiene una configuración digástrica, que tampoco coincide con ningún subtipo de la clasificación.

PALABRAS CLAVE: Miología; Músculo esternal; Músculo pectoral mayor; Variación anatómica.

\section{REFERENCIAS BIBLIOGRÁFICAS}

Aguado-Henche, S.; de Arriba, C. C. \& Cristóbal-Aguado, S. A right sternalis muscle: Clinical and surgical significance. J. Hum. Anat., 2(2):000126, 2018.

Cherian, S. B. \& Gandhalam, A. J. Rectus sternalis muscle: An anatomical variant of anterior chest wall. OA Anat., 2(2):16, 2014.

Diogo, R. \& Abdala, V. Muscles of Vertebrates: Comparative Anatomy, Evolution, Homologies and Development. New York, CRC Press, 2010.

Diogo, R. \& Wood, B. A. Comparative Anatomy and Phylogeny of Primate Muscles and Human Evolution. New York, CRC Press, 2012.

Federative International Committee on Anatomical Terminologies (FICAT). Terminologia Anatomica. International Anatomical Terminology. New York, Thieme, 1998.

Guru, A.; D’Souza, M.; Kumar, N.; Nayak, S. B.; Patil, J.; Shanthakumar, S. R. \& Aithal, A. A digastric sternalis muscle: a rare finding. OA Case Rep., 2(17):163, 2013.

Harish, K. \& Gopinath, K. S. Sternalis muscle: importance in surgery of the breast. Surg. Radiol. Anat.; 25(3-4):311-4, 2003.

Hermanson, J. W. The Muscular System. In: Evans, H. \& de Lahunta, A. (Eds.). Miller's Anatomy of the Dog. St. Louis, Saunders Elsevier, 2013. pp.185-280.

Hung, L. Y.; Lucaciu, O. C. \& Wong, J. J. Back to the Debate: Sternalis Muscle. Int. J. Morphol., 30(1):330-6, 2012.

Jelev, L.; Georgiev, G. \& Surchev, L. The sternalis muscle in the Bulgarian population: classification of sternales. J. Anat., 199(Pt. 3):359-63, 2001.

Katara, P.; Chauhan, S.; Arora, R. \& Saini, P. A unilateral rectus sternalis muscle: rare but normal anatomical variant of anterior chest wall musculature. J. Clin. Diagn. Res., 7(12):2665-7, 2013.

Kida, M. Y.; Izumi, A. \& Tanaka, S. Sternalis muscle: topic for debate. Clin. Anat., 13(2):138-40, 2000.

Kumar, H.; Rath, G.; Sharma, M.; Kohli, M. \& Rani, B. Bilateral sternalis with unusual left-sided presentation: a clinical perspective. Yonsei Med. J., 44(4):719-22, 2003.

Lander, K. F. The pectoralis minor: a morphological study. J. Anat., 52(Pt. 3):292-318, 1918.

Loukas, M.; Bowers, M. \& Hullett, J. Sternalis muscle: a mystery still. Folia Morphol. (Warsz), 63(2):147-9, 2004.

Marques, E. F.; Souza, J. A.; Graziano, L.; Vieira Bitencourt, A. G.; Senaga, C. \& Martins Fontes, C. E. Músculo esternal simulando nódulo mamário. Rev. Bras. Ginecol. Obstet., 31(10):492-5, 2009.

Mehta, V.; Arora, J.; Yadav, Y.; Suri, R. K. \& Rath, G. Rectus thoracis bifurcalis: a new variant in the anterior chest wall musculature. Rom.J. Morphol. Embryol., 51(4):799-801, 2010.

Ministerio de Salud. República de Colombia. Resolución Número 8430 de 1993. Por la cual se establecen las normas científicas, técnicas y administrativas para la investigación en salud. Bogotá, Ministerio de Salud. República de Colombia, 1993.

Motabagani, M. A.; Sonalla, A.; Abdel-Meguid, E. \& Bakheit, M. A. Morphological study of the uncommon rectus sterni muscle in German cadavers. East Afr. Med. J., 81(3):130-3, 2004.

O'Neill, M. N. \& Folan-Curran, J. Case report: bilateral sternalis muscles with a bilateral pectoralis major anomaly. J. Anat., 193(Pt. 2):289-92, 1998.

Pérez, J.; Pérez-Gumá, J. E.; Correa, R.; Rivera, M.; Castro, A.; Cedeño, J.; López, M.; Nazario, L.; Otero, K.; Quiles, J.; et al. Breast mass or sternalis muscle? P. R. Health Sci. J., 27(2):185, 2008.

Potau, J. M.; Arias-Martorell, J.; Bello-Hellegouarch, G.; Casado, A.; Pastor, J. F.; de Paz, F. \& Diogo, R. Inter- and intraspecific variations in the pectoral muscles of common Chimpanzees (Pan troglodytes), Bonobos (Pan paniscus), and Humans (Homo sapiens). BioMed Res., Int., 2018:9404508, 2018.

Poveda, C. A.; Muñoz, E. J. \& Camargo, D. C. Músculo esternalis: variante anatómica que simula neoplasia en mamografía. Rev. Colomb. Cancerol., 17(1):46-9, 2013. 
Preeti, T.; Harsha, B.; Ujwal, G.; Eti, S.; Sunita, B.; Manjiri, C. \& Bhaurao, B. The bilateral sternalis: an uncommon anatomical variant. J. Clin. Diagn. Res., 6(5):767-9, 2012.

Rahman, N. A.; Das, S.; Maatoq Sulaiman, I.; Hlaing, K. P.; Haji Suhaimi, F.; Latiff, A. A. \& Othman, F. The sternalis muscle in cadavers: anatomical facts and clinical significance. Clin. Ter, 160(2):129-31, 2009.

Raikos, A.; Paraskevas, G. K.; Tzika, M.; Faustmann, P.; Triaridis, S.; Kordali, P.; Kitsoulis, P. \& Brand-Saberi, B. Sternalis muscle: an underestimated anterior chest wall anatomical variant. J. Cardiothorac. Surg., 6:73, 2011.

Standring, S. Gray's Anatomy. The Anatomical Basis of Clinical Practice. $41^{\text {st }}$ ed. New York, Elsevier, 2016. pp. 1562.

Van der Broek, A. J. P. Ein doppelseitiger M.sternalis und ein M. pectoralis quartus bei Hylobates syndactylus. Anat. Anz., 35:591-6, 1909.

Vishal, K.; Kavitha, K.; Vinay, K. V. \& Raghavendra, A.Y. Unilateral rectus sternalis muscle: a case report. Nitte Univ. J. Health Sci., 3(1):66-8, 2013.

Young Lee, B.; Young Byun, J.; Hee Kim, H.; Sook Kim, H.; Mee Cho, S.; Hoon Lee, K.; Sup Song, K.; Soo Kim, B. \& Mun Lee, J. The sternalis muscles: incidence and imaging findings on MDCT. J. Thorac. Imaging, 21(3): 179-83, 2006.

Zaher, W. A.; Darwish, H. H.; Abdalla, A. M. E.; Vohra, M. S. \& Khan, M. M. Sternalis: a clinically important variation. Pak. J. Med. Sci., 25(2):325-8, 2009.
Corresponding author:

Jorge Eduardo Duque Parra

Departamento de Ciencias Básicas

Facultad de Ciencias para la Salud

Universidad de Caldas

Calle 65 \# 26-10

Manizales

COLOMBIA

\section{E-Mail:jduqueparra@yahoo.com.mx}

Recibido : 21-01-2019

Aceptado: 10-06-2019 